\title{
XXXV. Analyses of the hydrates of baryta and strontia
}

\section{Henry M. Noad Esq.}

To cite this article: Henry M. Noad Esq. (1837) XXXV. Analyses of the hydrates of baryta and strontia, Philosophical Magazine Series 3, 11:67, 301-302, DOI: 10.1080/14786443708649276

To link to this article: http://dx.doi.org/10.1080/14786443708649276

曲 Published online: 01 Jun 2009.

Submit your article to this journal \lceil

Џll Article views: 2

Q View related articles $\sqsubset$ 
tral fins are placed opposite each other, as also are the anal and what appears to be the posterior dorsal. Here a discrepancy exists. In recent Salmonidæ, the latter fin is merely a fleshy appendage, and not supported by rays. In the fossil specimen the fin, though imperfect, exhibits traces of true rays. Though this will prevent its being considered one of the Salmonidre, I know none other of the abdominal Malacopterygii that have the same arrangement of the fins: this fact, combined with the resemblance between the scales, which differ only in the existence of radiating striæ at one extremity of the fossil, which do not exist on the recent ones, seems to indicate a close affinity. The discovery of more complete specimens may throw new light upon their nature.

XXXV. Analyses of the Hydrates of Baryta and Strontia. By H. M. Noad, Esq., Lecturer on Chemistry.

\section{To the Editors of the Philosophical Magazine and Journal.} Gentlemen,

$\mathrm{O}^{\mathrm{N}}$ looking over some of the back Numbers of your Magazine, which have only lately come into my hands, I met with a paper by Mr. J. D. Smith on the hydrates of barytes and strontia, in which he seems to think that the previous determination of the quantity of water combined with these metallic oxides, by Mr. Phillips, is not correct. On referring to my journal, I found the results of an analysis of these hydrates by myself performed about two years ago, and having some crystals of each at the bottom of two bottles in which they had remained since that time, I determined to analyse them again, with the greatest care, as my results did not exactly correspond with those of Mr. Smith. As my recent experiments coincide exactly with my former ones, perhaps you will allow them to be inserted in your Journal, for the inspection of Mr. Smith and others. I must observe that the greatest care was taken to get the crystals perfectly dry by pressure between folds of blotting-paper.

$$
\begin{array}{lll} 
& \text { Bar. } \quad \text { Sulph. of Bar. Bar. } & \text { Water. } \\
\text { Exp. 1. } & 37.5 \text { gave } 26.75=17.56+19.94 \\
\text { Exp. 2. } & 30^{\circ} \text { gave } 21.5=14 \cdot 11+15.89 \\
\text { Exp. 3. } & 26 . & \text { gave } 18.62=\frac{12.42}{43.89}+\frac{13.78}{49.61}
\end{array}
$$

or 76.7 one equivalent of baryta combined with 86.69 nearly $9 \frac{3}{4}$ equivalents of water. 
Thirty grains of crystals of strontia dissolved in hot water, and precipitated by bicarbonate of potash, gave 16.5 of carbonate of strontia $=11.56$ strontia; a second thirty grains gave precisely the same result : so

Stron. Stron. Water.

$3011 \cdot 56+18 \cdot 44$, or, $51 \cdot 8$, one equivalent of strontia combined with $82 \cdot 62$, rather more than 9 equivalents of water.

Although these experiments do not agree with those either of Mr. Phillips or Mr. Smith, their coincidence with each other appears to show that these two metallic oxides do not behave precisely the same with respect to water.

I am, Gentlemen, yours, \&c.,

Shawford near Bath, Aug. 18, $1837 . \quad$ Henry M. Noad.

XXXVI. Analytical Investigation of Professor Wallace's Property of the Parabola. By J. R. Young, Esq., Professor of Mathematics in Belfast College.*

1 $\mathrm{N}$ the Philosophical Magazine for August 1836, a remarkable property of the parabola, first established by Professor Wallace, is made the subject of a communication from $\mathrm{Mr}$. Lubbock; in which communication that distinguished mathematician has given a proof of the theorem upon the principles of analytical geometry.

In a subsequent Nunber of the Magazine, that for January 1837, two other analytical investigations were given; one by Mr. Greatheed of 'Trinity, and the other by Mr. Holditch of Caius College, Cambridge; and a neat geometrical proof was at the same time offered, differing but little from that of Professor Wallace himself.

Ingenious and interesting as these several investigations are, they can, I think, scarcely be regarded as more than mere verifications, by analysis, of a previously known geometrical truth; in as much as they do not exhibit the steps by which an analyst would be likely to be led to such a property, unless it were anticipitated at the outset. It is certain also that no analytical investigation hitherto given is comparable, on the score of simplicity, with the geometrical proof; ahiough it would be premature to assert that analysis is incompetent to furnish a proof equally simple and elegant.

The investigation which I here offer is remarkably easy; it differs essentially from those hitherto given, and will I think bear a favourable comparison with the geometrical method.

* Commuricated by the Author. 